\title{
Spatio-Temporal Pattern of World Heritage and Its Accessibility Assessment in China
}

\author{
Yanjun Che ${ }^{1,2,3,4,5}$, Yun Cao ${ }^{2,3,4}$, Rong $\mathrm{Wu}^{1, *}$, Jian Liu ${ }^{1}$, Lihua Chen ${ }^{1,2,3}$ and Jiakang $\mathrm{Wu}^{1}$ \\ 1 Department of Geography Science, Yichun University, Yichun 336000, China; cheyanjun@jxycu.edu.cn (Y.C.); \\ hufg1112@jxycu.edu.cn (J.L.); chen_lihua@jxnu.edu.cn (L.C.); weihuang@jxycu.edu.cn (J.W.) \\ 2 Department of Physical Geography and Resources and Environment, School of Geography and Environment, \\ Jiangxi Normal University, Nanchang 330000, China; 004312@jxnu.edu.cn \\ 3 Nanchang Base of International Centre on Space Technologies for Natural and Cultural Heritage under the \\ Auspices of UNESCO, Nanchang 330000, China \\ 4 Key Laboratory of Poyang Lake Wetland and Watershed Research, Jiangxi Normal University, \\ Ministry of Education, Nanchang 330000, China \\ 5 Yulong Snow Mountain Glacier and Environment Observation and Research Station/State Key Laboratory of \\ Cryospheric Sciences, Northwest Institute of Eco-Environment and Resources, Chinese Academy of Sciences, \\ Lanzhou 730000, China \\ * Correspondence: wurong@jxycu.edu.cn
}

Citation: Che, Y.; Cao, Y.; Wu, R.; Liu, J.; Chen, L.; Wu, J. Spatio-Temporal Pattern of World Heritage and Its Accessibility Assessment in China. Sustainability 2022, 14, 3033. https:// doi.org/10.3390/su14053033

Academic Editors: Dimitrios Aidonis, Naoum Tsolakis and Charisios Achillas

Received: 23 December 2021 Accepted: 28 February 2022 Published: 4 March 2022

Publisher's Note: MDPI stays neutral with regard to jurisdictional claims in published maps and institutional affiliations.

Copyright: (C) 2022 by the authors. Licensee MDPI, Basel, Switzerland. This article is an open access article distributed under the terms and conditions of the Creative Commons Attribution (CC BY) license (https:// creativecommons.org/licenses/by/ $4.0 /)$.

\begin{abstract}
World Heritage is of high historical, artistic, and scientific value and represents wealth created by human beings or nature that cannot be replaced. In this paper, the tempo-spatial characteristics of World Heritage and its traffic accessibility were assessed in China using statistical and spatial analysis methods. The results showed that development of Chinese World Heritage experienced exploratory, evolution, accelerated development, and stable development phases. To date, there are 55 World Heritage Projects in China, including 37 Cultural Heritage, 14 Natural Heritage, and 4 mixed double heritage projects. Based on the spatial analysis, global spatial correlation of these heritage sites was not significant while the local spatial correlation was significant. The majority of the heritage sites were distributed in the east-central regions of China, and the hotspots were also concentrated in these regions. In addition, an assessment of inter-regional accessibility indicated that $63.18 \%$ of heritage sites could be reached within one hour from a city center and the average time taken to reach a heritage site was at $1.03 \mathrm{~h}$ in the local city. Time cost was low and accessibility was good. Additionally, an analysis of the overall accessibility showed that the average time cost of the World Heritage Sites was $25.51 \mathrm{~h}$. Overall accessibility in the central plain region of China was very high, with a time cost of $<15 \mathrm{~h}$. The overall accessibility in the western mountains and northeastern regions was very limited. In general, the development of China's World Heritage still has great potential and strong traffic accessibility, which can effectively promote the development of heritage tourism. Meanwhile, heritage tourism can also effectively promote the development of local economies under the principle of protection priority.
\end{abstract}

Keywords: world heritage; accessibility; China; Moran's I; spatial distribution

\section{Introduction}

World Heritage refers to cultural relics and natural landscapes with outstanding significance or universal value as selected by the United Nations Educational, Scientific, and Cultural Organization (UNESCO) and recorded in the World Heritage List [1-3]. They have high historical, artistic, and scientific value so they are rare and irreplaceable. To sustainably develop the precious natural and cultural heritage resources around the world, the World Cultural and Natural Heritage Protection Convention was signed on 17 November 1972 by UNESCO [4]. In the convention, Cultural Heritage was defined as the works of man, as well as the combined works of nature and of man and areas representing exceptional universal interest from historical, aesthetic, and ethnographic 
points of view, including archaeological sites (https:/ /whc.unesco.org/en/documents/ 1471 (accessed on 20 December 2021)). Natural Heritage was defined as natural sites or strictly delineated natural areas of outstanding universal interest from the point of view of science, conservation, and natural beauty, including natural monuments, geological, and physiographical formations and precisely delineated areas. Although Mixed Heritage sites were not announced until 2005, a case of Mixed Heritage occurred in 1979. The Tikal National Park in Guatemala was added to the World Heritage List because it met criteria (i), (iii), (iv), (ix), and (x). Criterion (i) was described as "the Tikal National Park is an outstanding example of the art and human genius of the Maya", while criterion (ix) was described as "the landscape mosaic comprising savannas, lush forests, wetlands and various freshwater systems is part of the Maya Forest, one of the conservation gems of Central America, hosting a rich diversity of flora and fauna as a result of a remarkable evolution of species and ecological communities" (https://whc.unesco.org/en/list/64/ (accessed on 20 December 2021)).

In 1976, the World Heritage Commission was established. Member states submitted their World Heritage Sites to UNESCO the World Heritage List was established. The concept of Mixed Heritage was named and listed as a type of World Heritage in 2005, at which point it was also proposed that the nomination of Mixed Heritage should be given priority in order to enhance the balance of the list [5]. Mixed Heritage, i.e., Mixed Cultural and Natural Heritage, is defined as "satisfy[ing] a part or the whole of the definitions of both Cultural and Natural Heritages laid out in Articles 1 and 2 of the Convention" (http:/ / whc.unesco.org/en/guidelines/ (accessed on 9 January 2021)). World Heritage was subsequently classified as World Cultural Heritage, World Natural Heritage or World Mixed Heritage. Based on the continuous development of the norms of World Heritage over past decades, World Heritage-listed landscapes must meet at least one or more of 10 standards to be considered of outstanding universal value [1,6-8]. Until November 2020, the 1121 World Heritage items were listed on the World Heritage List, including 869 World Cultural Heritage sites, 213 World Natural Heritage sites and 39 World Mixed Heritages sites [9]. Additionally, 53 sites were listed as endangered heritages.

China's government submitted the Chinese World Heritage Project to UNESCO in 1986, and six heritage sites were first listed on the UNESCO World Heritage List in December 1987 [3,10]. So far, there are more than 50 World Heritage Projects in China. As in the number and fame of World Heritage Sites increased, there was a contradiction between the World Heritage Site's protection and the people's eagerness to explore the sites due to curiosity. "Heritage tourism" gradually grew, which allowed this contradiction to be solved in a way that was conducive to the sustainable economic development of the localities of the heritage sites $[6,7,11-13]$. With the improvement of human material wealth and intellectual curiosity, there was a gradual increase in interest among non-heritage residents who wanted to learn about World Heritage culture and landscapes through tourism [14]. The accessibility of World Heritage Sites became the key factor affecting residents' travel. Therefore, it becomes particularly necessary to understand spatial patterns and assess the transportation accessibility of World Heritage Sites. Although research on the number of heritage sites and their spatial distribution was conducted in China [7,11,15-17], such research has not been conducted on the exploratory space and traffic accessibility of Chinese World Heritage Sites.

In this paper, our main aims were to understand the development of World Heritage Projects and to assess their spatial pattern in China in order to (I) understand the development of World Heritage in China and its current state; (II) explore the spatial pattern of China's World Heritage Sites; and (III) assess the traffic accessibility of these World Heritage Sites in China. To achieve these research goals, we collected data on World Heritage Projects and roads in China. Some timing analysis methods and spatial analysis techniques were used to understand the spatiotemporal characteristics and traffic accessibility of various sites. The results will be used as a reference for the nomination, protection, and tourism development of World Heritage. In particular, the study of the spatial patterns of World 
Heritage can provide a reference for the Chinese government to balance these nominations. The results of traffic accessibility will provide information for people who want to visit World Heritage Sites and for local governments to help them to implement plans for World Heritage Projection.

\section{Data and Methodology}

\subsection{Data Sources and Collection}

The data involved in this study mainly included World Heritage Project data and map data. The data records of World Heritage Projects contained information on Cultural, Natural and Mixed Heritage sites in China, while the map data mainly involved the roads and administrative boundaries in China. Information on World Heritage Projects was derived from the World Heritage Center on the UNESCO website (https:/ / whc.unesco. org/en/list/ (accessed on 12 September 2021)), which was accurate up to December 2020. The Chinese administrative map was downloaded from the standard map service website of the National Administration of Surveying, Mapping and Geo information (http:/ / bzdt.ch.mnr.gov.cn / (accessed on 21 September 2021)). In addition, a traffic network dataset was used to calculate the time cost of heritage travel based on Gaode Map (https: / / www.amap.com/ (accessed on 12 September 2021)). For detailed information on the dataset please see Table 1 .

Table 1. Data sources used in the study.

\begin{tabular}{ccc}
\hline Data Items & Forms & Reference \\
\hline Cultural Heritage & $. x l s / \mathrm{kml}$ & $\mathrm{https} / /$ whc.unesco.org/en/syndication \\
Natural Heritage & $. x \mathrm{~s} / \mathrm{kml}$ & $\mathrm{https} / /$ whc.unesco.org/en/syndication \\
Mixed Heritage & $. x l s / \mathrm{kml}$ & $\mathrm{https} / / \mathrm{whc}$.unesco.org/en/syndication \\
Highway dataset & $. \mathrm{shp} / \mathrm{kml}$ & $\mathrm{https} / /$ ditu.amap.com/ \\
Administrative boundaries & .shp/eps & http://bzdt.ch.mnr.gov.cn/ \\
\hline
\end{tabular}

\subsection{Analysis Methods}

\subsubsection{Global Spatial Analysis of Spatial Pattern of World Heritage Sites}

To explore the distribution of World Heritage Sites in space, global Moran's I indexes were used in this paper. The global Moran's I indicates the similarity between the distribution of the values of spatial adjacency or spatial adjacency regional units [18,19]. The value of Moran's I ranges from -1 to 1 , where a value of less than 0 represented a negative correlation, equal to 0 represented no correlation, and more than 0 represented a positive correlation. The formula of Moran's I is as follows:

$$
I=\frac{n \sum_{i=1}^{n} \sum_{j=1}^{n} w_{i j}\left(x_{i}-\bar{x}\right)\left(x_{j}-\bar{x}\right)}{\sum_{i=1}^{n} \sum_{i=j}^{n} w_{i j} \sum_{i=1}^{n}\left(x_{i}-\bar{x}\right)^{2}}
$$

where $I$ indicates the value of the Global Moran's I, $w_{i j}$ indicates the spatial weight of the two elements $i$ and $j, x_{i}$ indicates the attribute value of the element $\mathrm{I}$, and $\bar{x}$ indicates the average value of the elements. The formula of the average value is defined as follows:

$$
\bar{x}=\frac{\sum_{j=1}^{n} x_{j}}{n}
$$


For Moran's I, a standardized statistic variation of $Z$ can be used to test whether there is a significant spatial autocorrelation, and its formula is defined as follows:

$$
Z=\frac{I-E(I)}{\sqrt{\operatorname{Var}(I)}}
$$

where a positive and significant $Z$ indicates a positive spatial autocorrelation; that is, similar observations of high or low values tending towards spatial agglomeration. A negative and significant $Z$ indicates a negative spatial autocorrelation and shows that the values are discretely distributed in space. A $Z$ of zero indicates an independent random distribution.

\subsubsection{Local Spatial Analysis of Spatial Pattern in the World Heritage Sites}

Although the global spatial autocorrelation index (Moran's I) can reveal the spatial heterogeneity of the global variables, it does not accurately reflect the spatial relations of the local variables, which are sometimes masked. To further explore the spatial autocorrelation of the local variables, the Getis-Ord $\mathrm{Gi}^{*}$ index was used to reveal the spatial distribution characteristics of heritage sites, the formula of which is defined as follows:

$$
G_{i}^{*}=\frac{\sum_{j=1}^{n} \omega_{i, j} x_{j}-\bar{X} \sum_{j=1}^{n} \omega_{i, j}}{S \sqrt{\frac{\left[n \sum_{j=1}^{n} \omega_{i, j}^{2}-\left(\sum_{j=1}^{n} \omega_{i, j}\right)^{2}\right]}{n-1}}}
$$

where $x_{j}$ represents the attribute value of the element $j, \omega_{i, j}$ indicates the spatial weight between the elements $i$ and $j, n$ represents the total number of the elements in space, and the calculated statistic value of the $G_{i}^{*}$ is the score of $Z . S$ is defined as follows:

$$
S=\sqrt{\frac{\sum_{j=1}^{n} x_{j}^{2}}{n}-(\bar{x})^{2}}
$$

\subsubsection{Traffic Accessibility in Terms of the Time Cost}

Accessibility usually refers to how easy it is to get to a heritage site from different places, which can be divided into inter-regional and extra-regional accessibility $[14,20,21]$. In this paper, the inter-regional accessibility showed the ease of reaching heritage sites in a small area, which was measured by the time distance [22]. Due to the short internal distance of the area, visitors mainly went to the heritage site by road. The time cost was represented by the prefecture-level city government center as the place of departure, with each heritage point as the destination.

Extra-regional accessibility referred to the ease of reaching a regional heritage site from other areas of the country, measured by the average shortest time distance [22]. Here, we used ArcGIS's O-D cost matrix analysis to calculate the time cost between all prefecturelevel cities in China to obtain the average time cost of getting from a certain city to other regions. Comprehensive accessibility was the sum of inter-regional accessibility and extraregional accessibilities. Based on the requirements of the Highway Engineering Technical Standards of the People's Republic of China (JTGB-2003), the road speed was defined on highways as $100 \mathrm{~km}$ per hour, on national highways as $80 \mathrm{~km}$ per hour, and on provincial highways as $60 \mathrm{~km}$ per hour. The formula used to calculate the accessibility of the heritage sites in China in this paper is as follows:

$$
\mathrm{T}=\mathrm{L} / \mathrm{S}
$$

where the $\mathrm{T}$ denotes the time cost, L denotes the total distance from departure to destination, and $S$ denotes the speed per hour. 


\section{Results}

\subsection{Change in China's World Heritage Development}

Since China joined the World Heritage Convention in 1985, 55 items from China have been added to the UNESCO World Heritage List (Figure 1), with China now ranking first in the world in terms of number. These 55 items include 37 World Cultural Heritage sites, 14 World Natural Heritage sites and 4 World Mixed Cultural and Natural Heritage sites (also called Double Heritage sites) (Table 2). The development of China's World Heritage Project can be divided into four phases. The exploratory stage encompasses the period prior to 1985. Many exploratory studies on the concept and nomination of World Heritage Sites were conducted in this period. Secondly, the evolution stage is defined as the period 1986-1999. In 1987, UNESCO for the first time announced that six heritage sites from China were included on the World Heritage List, i.e., Mausoleum of the First Qin Emperor, the Great Wall, Imperial Palaces of the Ming and Qing Dynasties in Beijing, Peking Man Site at Zhoukoudian, Mogao Caves and Mount Taishan. Only one additional heritage site was added from 1989 to 1991, while the number of heritage sites had increased to 23 by 1999 . Thirdly, the accelerated development stage is defined as the period 2000-2003. In 2000, four new World Natural Heritage sites added in China. Finally, the stable development stage is defined as after 2003. The number of heritage sites has steadily increased every year since 2004, which indicates that it began to enter its growth stage. While China's number of Cultural Heritage Sites increased rapidly in this period, its number of Mixed Heritage Sites has remained unchanged since 1999. To date, only six provincial administrative regions have no World Heritage Sites, including Shanghai, Heilongjiang, Hainan, Taiwan, Ningxia Hui Autonomous Region, and the Hong Kong Special Administrative Region.

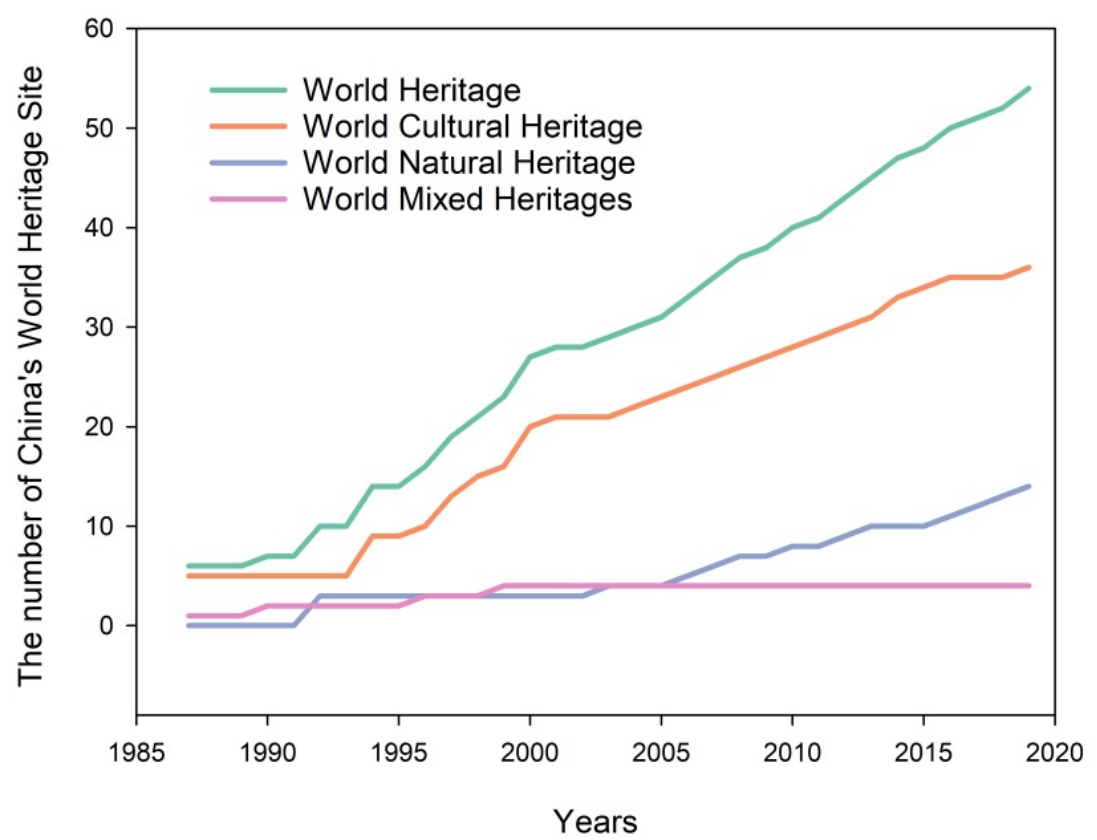

Figure 1. Changes in the development of China's World Heritage Sites. 
Table 2. World Heritage Sites in China and the criteria they meet.

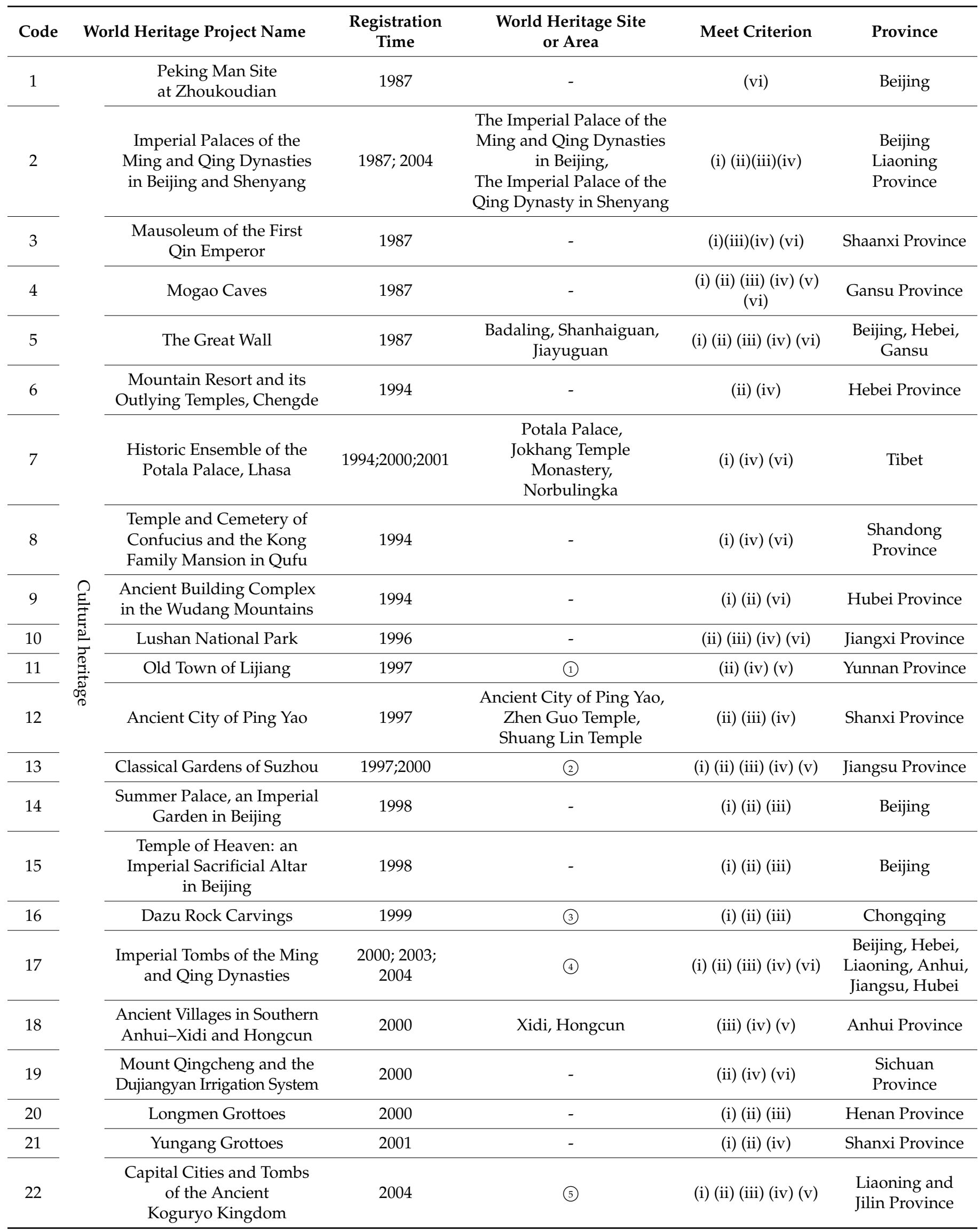


Table 2. Cont.

\begin{tabular}{|c|c|c|c|c|c|c|}
\hline Code & & orld Heritage Project Name & $\begin{array}{l}\text { Registration } \\
\text { Time }\end{array}$ & $\begin{array}{c}\text { World Heritage Site } \\
\text { or Area }\end{array}$ & Meet Criterion & Province \\
\hline 23 & & Historic Centre of Macao & 2005 & $\begin{array}{c}\text { Zone } 1 \text { (Between Mount } \\
\text { Hill and Barra Hill), Zone } \\
2 \text { (Guia Hill) }\end{array}$ & (ii) (iii) (iv) (vi) & Macao \\
\hline 24 & & Yin $\mathrm{Xu}$ & 2006 & $\begin{array}{c}\text { Palace and Royal } \\
\text { Ancestral Shrines Area, } \\
\text { Royal Tombs Area }\end{array}$ & (ii) (iii) (iv) (vi) & Henan Province \\
\hline 25 & & Kaiping Diaolou and Villages & 2007 & (6) & (ii) (iii) (iv) & $\begin{array}{l}\text { Guangdong } \\
\text { Province }\end{array}$ \\
\hline 26 & & Fujian Tulou & 2008 & (7) & (iii) (iv) (v) & Fujian Province \\
\hline 27 & & Mount Wutai & 2009 & Taihuai, Foguang Temple & (ii) (iii) (iv) (vi) & Shanxi Province \\
\hline 28 & & $\begin{array}{l}\text { Historic Monuments of } \\
\text { Dengfeng in "The Centre of } \\
\text { Heaven and Earth" }\end{array}$ & 2010 & (8) & (iii) (vi) & Henan Province \\
\hline 29 & & $\begin{array}{c}\text { West Lake Cultural } \\
\text { Landscape of Hangzhou }\end{array}$ & 2011 & - & (ii) (iii) (vi) & $\begin{array}{l}\text { Zhejiang } \\
\text { Province }\end{array}$ \\
\hline 30 & & Site of Xanadu & 2012 & - & (ii) (iii) (iv) (vi) & $\begin{array}{l}\text { Inner Mongolia } \\
\text { Autonomous } \\
\text { Region }\end{array}$ \\
\hline 31 & & $\begin{array}{c}\text { Cultural Landscape of } \\
\text { Honghe Hani Rice Terraces }\end{array}$ & 2013 & - & (iii) (v) & Yunnan Province \\
\hline 32 & & $\begin{array}{l}\text { Silk Roads: the Routes } \\
\text { Network of Chang'an- } \\
\text { Tianshan Corridor }\end{array}$ & 2014 & (9) & (ii) (iii) (v) (vi) & $\begin{array}{c}\text { China, } \\
\text { Kazakhstan, } \\
\text { and Kyrgyzstan }\end{array}$ \\
\hline 33 & & The Grand Canal & 2014 & (10) & (i) (iii) (iv) (vi) & $\begin{array}{c}\text { Beijing, Tianjin, } \\
\text { Hebei, Shandong, } \\
\text { Henan, Anhui, } \\
\text { Jiangsu, Zhejiang }\end{array}$ \\
\hline 34 & & Tusi Sites & 2015 & (11) & (ii) (iii) & $\begin{array}{l}\text { Hunan, Hubei, } \\
\text { Guizhou }\end{array}$ \\
\hline 35 & & $\begin{array}{l}\text { Zuojiang Huashan Rock Art } \\
\text { Cultural Landscape }\end{array}$ & 2016 & $\begin{array}{l}\text { Ningming and Longzhou } \\
\text { County rock art, Longhzou } \\
\text { County rock art, Jiangzhou } \\
\text { District, Fusui County } \\
\text { rock art }\end{array}$ & (iii) (vi) & Guangxi Province \\
\hline 36 & & $\begin{array}{c}\text { Kulangsu, a Historic } \\
\text { International Settlement }\end{array}$ & 2017 & - & (ii) (iv) & Fujian Province \\
\hline 37 & & $\begin{array}{l}\text { Archaeological Ruins of } \\
\text { Liangzhu City }\end{array}$ & 2019 & (12) & (iii) (iv) & $\begin{array}{l}\text { Zhejiang } \\
\text { Province }\end{array}$ \\
\hline 38 & \multirow{4}{*}{ 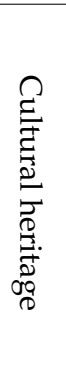 } & $\begin{array}{l}\text { Jiuzhaigou Valley Scenic } \\
\text { and Historic Interest Area }\end{array}$ & 1992 & - & (vii) & $\begin{array}{l}\text { Sichuan } \\
\text { Province }\end{array}$ \\
\hline 39 & & $\begin{array}{l}\text { Wulingyuan Scenic and } \\
\text { Historic Interest Area }\end{array}$ & 1992 & - & (vii) & Hunan Province \\
\hline 40 & & $\begin{array}{l}\text { Huanglong Scenic and } \\
\text { Historic Interest Area }\end{array}$ & 1992 & - & (vii) & $\begin{array}{l}\text { Sichuan } \\
\text { Province }\end{array}$ \\
\hline 41 & & $\begin{array}{l}\text { Three Parallel Rivers of } \\
\text { Yunnan Protected Areas }\end{array}$ & 2003 & - & (vii) (viii) (ix) (x) & Yunnan Province \\
\hline
\end{tabular}


Table 2. Cont.

\begin{tabular}{|c|c|c|c|c|c|c|}
\hline Code & & Jorld Heritage Project Name & $\begin{array}{l}\text { Registration } \\
\text { Time }\end{array}$ & $\begin{array}{c}\text { World Heritage Site } \\
\text { or Area }\end{array}$ & Meet Criterion & Province \\
\hline 42 & & $\begin{array}{c}\text { Sichuan Giant Panda } \\
\text { Sanctuaries-Wolong, Mt } \\
\text { Siguniang and Jiajin } \\
\text { Mountains }\end{array}$ & 2006 & - & $(x)$ & $\begin{array}{l}\text { Sichuan } \\
\text { Province }\end{array}$ \\
\hline 43 & & South China Karst & $2007 ; 2014$ & (13) & (vii) (viii) & $\begin{array}{l}\text { Guizhou, } \\
\text { Guangxi, } \\
\text { Yunnan, } \\
\text { Chongqing }\end{array}$ \\
\hline 44 & & $\begin{array}{l}\text { Mount Sanqingshan } \\
\text { National Park }\end{array}$ & 2008 & - & (vii) & Jiangxi Province \\
\hline 45 & & China Danxia & 2010 & (14) & (vii) (viii) & $\begin{array}{c}\text { Guangdong, } \\
\text { Zhejiang, } \\
\text { Jiangxi, Fujian, } \\
\text { Hunan, Guizhou }\end{array}$ \\
\hline 46 & & Chengjiang Fossil Site & 2012 & - & (viii) & Yunnan Province \\
\hline 47 & & Xinjiang Tianshan & 2013 & (15) & (vii) (ix) & $\begin{array}{l}\text { Xinjiang } \\
\text { Province }\end{array}$ \\
\hline 48 & & Hubei Shennongjia & 2016 & $\begin{array}{l}\text { Shennongding, } \\
\text { Laojunshan }\end{array}$ & (ix) (x) & Hubei Province \\
\hline 49 & & Qinghai Hoh Xil & 2017 & - & (vii) $(\mathrm{x})$ & $\begin{array}{l}\text { Qinghai } \\
\text { Province }\end{array}$ \\
\hline 50 & & Fanjingshan & 2018 & - Zhoukou dian & $(\mathrm{x})$ & $\begin{array}{l}\text { Guizhou } \\
\text { Province }\end{array}$ \\
\hline 51 & & $\begin{array}{c}\text { Migratory Bird Sanctuaries } \\
\text { along the Coast of Yellow } \\
\text { Sea-Bohai Gulf of China } \\
\text { (Phase I) }\end{array}$ & 2019 & $\begin{array}{l}\text { Migratory Bird Habitat in } \\
\text { the South of Yancheng, } \\
\text { Jiangsu, Migratory Bird } \\
\text { Habitat in the North of } \\
\text { Yancheng, Jiangsu }\end{array}$ & $(x)$ & Jiangsu Province \\
\hline 52 & \multirow{4}{*}{ 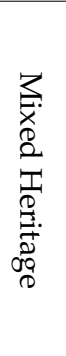 } & Mount Taishan & 1987 & - & $\begin{array}{l}\text { (i) (ii) (iii) (iv) (v) } \\
\text { (vi) (vii) }\end{array}$ & $\begin{array}{l}\text { Shandong } \\
\text { Province }\end{array}$ \\
\hline 53 & & Mount Huangshan & 1990 & - & (ii) (vii) (x) & Anhui Province \\
\hline 54 & & $\begin{array}{c}\text { Mount Emei Scenic Area, } \\
\text { including Leshan Giant } \\
\text { Buddha Scenic Area }\end{array}$ & 1996 & $\begin{array}{c}\text { Mount Emei Scenic Area, } \\
\text { Leshan Giant Buddha } \\
\text { Scenic Area }\end{array}$ & (iv) (vi) (x) & Sichuan Province \\
\hline 55 & & Mount Wuyi & 1999 & $\begin{array}{l}\text { Mount Wuyi (Part 1), } \\
\text { Mount Wuyi (Part 2) }\end{array}$ & (iii) (vi) (vii) (x) & Fujian Province \\
\hline
\end{tabular}

Note: A series of heritage sites, (1) Dayan Old Town, Heilongtan Pool, Baisha Village, Shuhe Town. (2) The Humble Administrator's Garden, The Lingering Garden, The Master-of-Nets Garden, The Mountain Villa with Embracing Beauty, The Canglang Pavilion, The Lion Forest Garden, The Garden of Cultivation, The Couple's Retreat, The Retreat and Reflection Garden. (3) Beishan Cliffside Carvings, Baodingshan Cliffside Carvings, Nanshan Cliffside Carvings, Shizhuanshan Cliffside Carvings, Shimenshan Cliffside Carvings. (4) Xianling Tomb, Eastern Qing Tombs, Western Qing Tombs, Ming Tombs, Xiaoling Tomb including area from Treasure Mound to Shenlieshan Stele, including Plum Blossom Hill, and Big Golden Gate, Tomb of Chang Yuchun, Tomb of Qiu Cheng, Tomb of $\mathrm{Wu}$ Liang, Tomb of Wu Zhen, Tomb of Xu Da, Tomb of Li Wenzhong, Yongling Tomb of the Qing Dynasty, Fuling Tomb of the Qing Dynasty, Zhaoling Tomb of the Qing Dynasty. (5) Wunu Mountain City, Guonei City, Wandu Mountain City, Ranmou Tomb and Huanwen Tomb, Changchuan Tomb No. 1, 2, 4. (6) Yinglong Lou (at Sanmenli Village), Zili Village and the Fang Clan Watch Tower, Majianlong Village Cluster, Jingjiangli Village. (7) Chuxi Tulou Cluster, Hokgkeng Tulou Cluster, Gaobei Tulou Cluster, Yanxiang Lou, Zhenfu Lou, Tianloukeng Tulou Cluster, Hekeng Tulou Cluster, Huaiyuan Lou, Hegui Lou, Dadi Tulou Cluster. (8) Taishi Que Gates, Zhongue Temple, Shaoshi Que Gates, Qimu Que Gates, Songye Temple Pagoda, Architectural Complex of Shaolin Temple (Kernel Compound, Chuzu Temple, Pagoda Forest), Huishan Temple, Songyang Academy of Classical Learning, Observatory. (9) Site of Weiyang Palace in Chang'an City of the Western Han Dynasty, Site of Luoyang City from the Eastern Han to Northern Wei Dynasty, Site of Daming Palace in Chang'an City of Tang Dynasty, Site of Dingding Gate, Luoyang City of Sui and Tang Dynasties, Site of Qocho City, Site of Yar City, Site of Bashbaliq City, 
Site of Han'gu Pass of Han Dynasty in Xin'an County, Site of Shihao Section of Xiaohan Ancient Route, Site of Suoyang City, Site of Xuanquan Posthouse, Site of Yumen Pass, Kizilgaha Beacon Tower, Kizil Cave-Temple Complex, Subash Buddhist Ruins, Bingling Cave-Temple Complex, Maijishan Cave-Temple Complex, Bin County Cave Temple, Great Wild Goose Pagoda, Small Wild Goose Pagoda, Xingjiaosi Pagodas, Tomb of Zhang Qian. (10) Site No. 160 of Hanjia Granary, Site of Huiloa Granary, Zhengzhou Section of Tongji Canal, Shangqiu Nanguan Section of Tongji Canal, Shangqiu Xiayi Section of Tongji Canal, Canal Site at Liuzi, Si County Section of Tongji Canal, Hua County and Xun County Section of Wei Canal (Yongii Canal), Site of Liyang Granary, Qingkou Complex, Site of Caoyun Governor's Mansion, Yangzhou Section of Huaiyang Canal, Changzhou City Section of Jiangnan Canal, Wuxi City Section of Jiangnan Canal, Suzhou Section of Jiangnan Canal, Jiaxing-Hangzhou Section of Jiangnan Canal, Nanxun Section of Jiangnan Canal, Hangzhou Xiaoshan-Shaoxing Section of Zhedong Canal, Shangyu-YuyaoSection of Zhedong Canal, Ningbo Section of Zhedong Canal, Ningbo Sanjiangkou, Old Beijing City Section of Tonghui Canal, Tongzhou Section of Tonghui Canal, Sanchkou Section of Bei Canal and Nana Canal in Tianjin, Cangzhou-Dezhou Section of Nan Canal, Linqing Section of Huitong Canal, Yanggu Section of Huitong Canal, Nanwang Complex, Weishan Section of Huitong Canal, Taierzhuang Section of Zhong Canal, Suqian Section of Zhong Canal. (11) Site of Laosicheng Tusi Domain, Site of Tangya Tusi Domain, Site of Hailongtun Tusi Fortress. (12) Area of Yaoshan Site, Area of High-dam at the Mouth of the Valley, Area of Low-dam on the Plain-Causeway in Front of the Mountains, Area of City Site. (13) Shilin Karst-Naigu Stone Forest, Shilin Karst-'Suogeyi Village', Libo Karst-'Xiaoqijong', Libo Karst-'Dongduo', Wulong Karst-Qingkou Giant Doline (Tiankeng), Wulong Karst-Three Natural Bridges, Wulong Karst-Furong Cave, Guilin Karst-Putao Fenling Karst Section, Guilin Karst-Lijiang Fengcong Karst Section, Shibing Karst, Jinfoshan Karst, Huanjiang Karst. (14) Chishui-West Section, Chishui-East Section, Taining-North Section, Taining-South Section, Langshan, Danxiashan, Longhushan: Longhushan Section, Longhushan: Guifeng Section, Jianglangshan. (15) Tomur, KalajunKuerdening, Bayinbuluke, Bogda.

\subsection{Pattern and Correlation in Spatial Distribution of Chinese World Heritage Site}

The research on China's World Heritage started late, but the speed at which it progressed was fast. China's World Heritage Sites now cover all types of World Heritage, comprise a large number of sites, and have a relatively wide coverage area. In order to explore the spatial structure of domestic World Heritage Sites, we explored the spatial distribution structure. As shown in Figure 2, China's World Heritage Sites are mainly distributed in the northwestern and southeastern regions of China. In the northwestern region of China, World Heritage Sites are concentrated along the Tien Shan and Hexi Corridor. Other areas exhibit scattered distributions. To explore the spatial dependence, correlation and autocorrelation of the distribution of the World Heritage Sites, a Moran 's I of the global spatial autocorrelation variable were used herein to assess the spatial distribution pattern. Based on the tools of spatial analysis in ArcGIS software, the Moran's I of Chinese World Heritage Sites were calculated to have a value of $0.019(p=0.2)$. This indicates that there is a weak spatial positive correlation in the spatial distribution of the heritage sites, but it does not pass the significance level test; that is, the spatial correlation shown by the spatial distribution location was not significant.

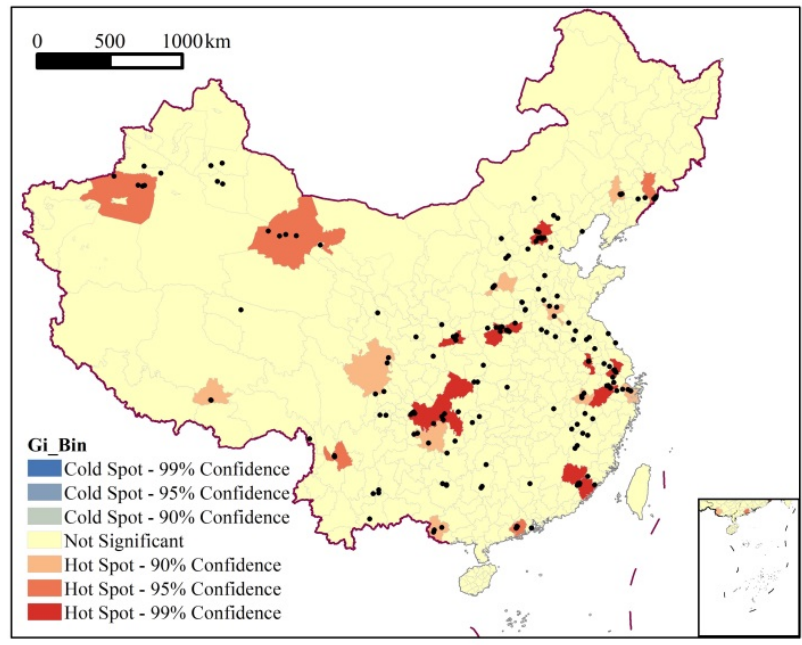

Figure 2. Spatial distribution of the cold-hot spots of Chinese World Heritage Sites.

To further explore the local internal structure of the spatial distribution of Chinese World Heritage Sites, the local spatial correlation index of Getis-Ord Gi* index was used, 
and its calculated results were visualized by the spatial analysis model of the ArcGIS platform. The index of local Getis-Ord Gi* was classified into five types from high to low using a natural fracture method, including hot spot, secondary hot spot, transition zone, secondary cold spot, and cold spot areas. The results showed that the correlation pattern of China's World Heritage in space showed obvious regional differentiation (Figure 2). The hot spots were mainly distributed in northwestern, central, and southeastern coast regions in China. The regional spatial correlation effect was significant, forming a contiguous high value area in Beijing-Tianjin-Hebei, Xi'an, Luoyang-Zhengzhou, Chongqing, the Yangtze River Delta, the Pearl River Delta, and northwest Hexi. In addition, the heritage sites of the rest of the eastern monsoon area were distributed in scattered points, while heritage sites are relatively rare in the northeast and the Qinghai-Tibet Plateau. With the continuous increase in China's applications for World Heritage Site recognition, however, these regions show great potential for World Heritage work in the future.

\subsection{Assessment of Internal Regional Accessibility}

We acknowledge that local residents have been the most involved group in the reginal World Heritage Sites. In this paper, the analysis of accessibility in the internal region has been focused on the differentiation assessment of local accessibility in a prefecture-level city. As shown in Figure 3a, the inter-regional accessibility of heritage sites in the eastern region was good within one hour, resulting from a flat terrain, dense road network, and developed transportation. However, there was a large difference in northwestern China in terms of the inter-regional accessibility due to its geographical position and properties. For example, some Word Heritage Sites of the Tien Shan Mountains are mainly concentrated in high mountainous zones with bad roads. In addition, the accessibility of the Qinghai-Tibet Plateau is also poor due to the poor transportation conditions in the plateau area. Based on the statistic of time spent on heritage site accessibility, we found that $39.30 \%$ of heritage sites could be reached within $0.5 \mathrm{~h}, 63.18 \%$ within $1 \mathrm{~h}, 88.56 \%$ within $2 \mathrm{~h}$, and $93.03 \%$ within $3 \mathrm{~h}$ starting from the local city center (Figure 3b). Overall, most of the Word Heritage Sites in China showed good accessibility with an average required time of $1.03 \mathrm{~h}$.
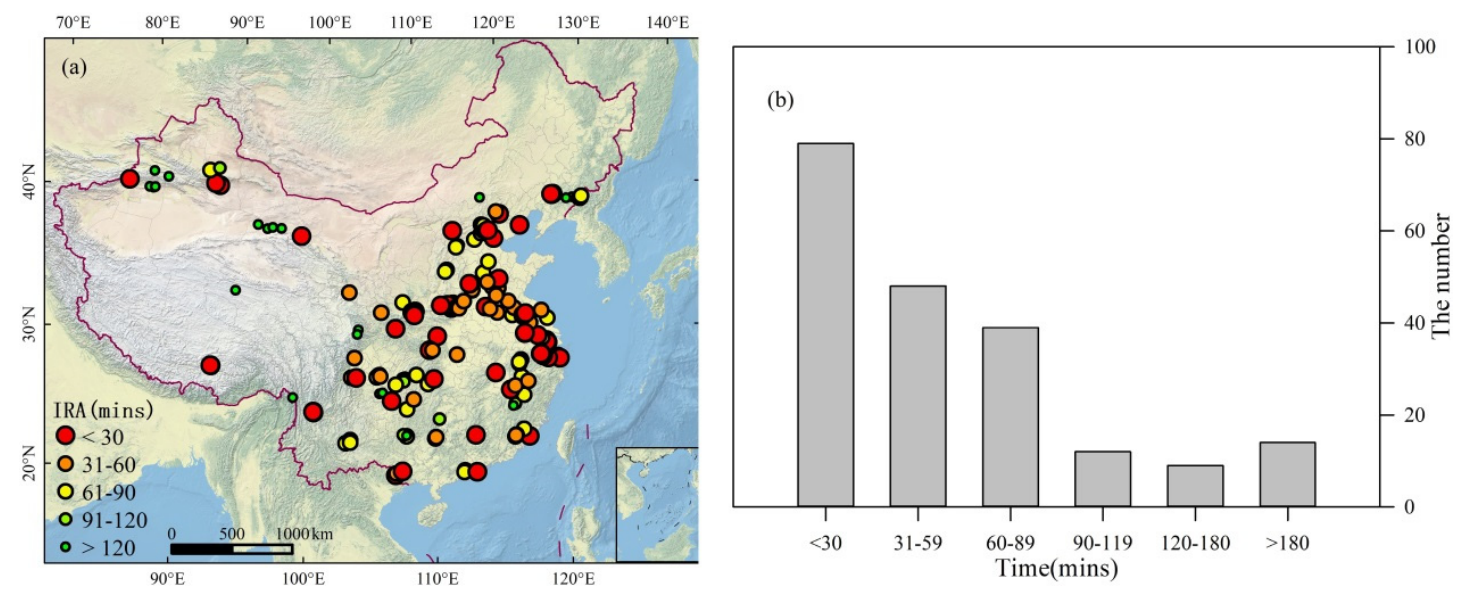

Figure 3. Distribution of regional accessibility and time cost of World Heritage Sites in China. In plots, (a) denotes inter-regional accessibility (IRA), i.e., the time cost of a city centre to a heritage site; (b) denotes the number of world heritage sites with different time cost in China.

\subsection{Assessment of Overall Accessibility}

Outer-regional accessibility presents the average time it takes tourists to travel from one city to another city with a World Heritage Site. It can reflect the convenience of the national road network distribution and the location advantage of a region. As shown in Figure $4 \mathrm{a}$, the results showed that the outer-regional accessibility in the central region of eastern China showed a good time with no more than $15 \mathrm{~h}$. In this region, the accessibility was significantly more convenient than other regions due to a plain terrain and dense 
traffic network. With an increase in distance and complexity of ground terrain in the west and northeast, the accessibility of World Heritage generally declined. In the Tien Shan Mountains of southwest China, especially, roads are bad, and its accessibility is not good.
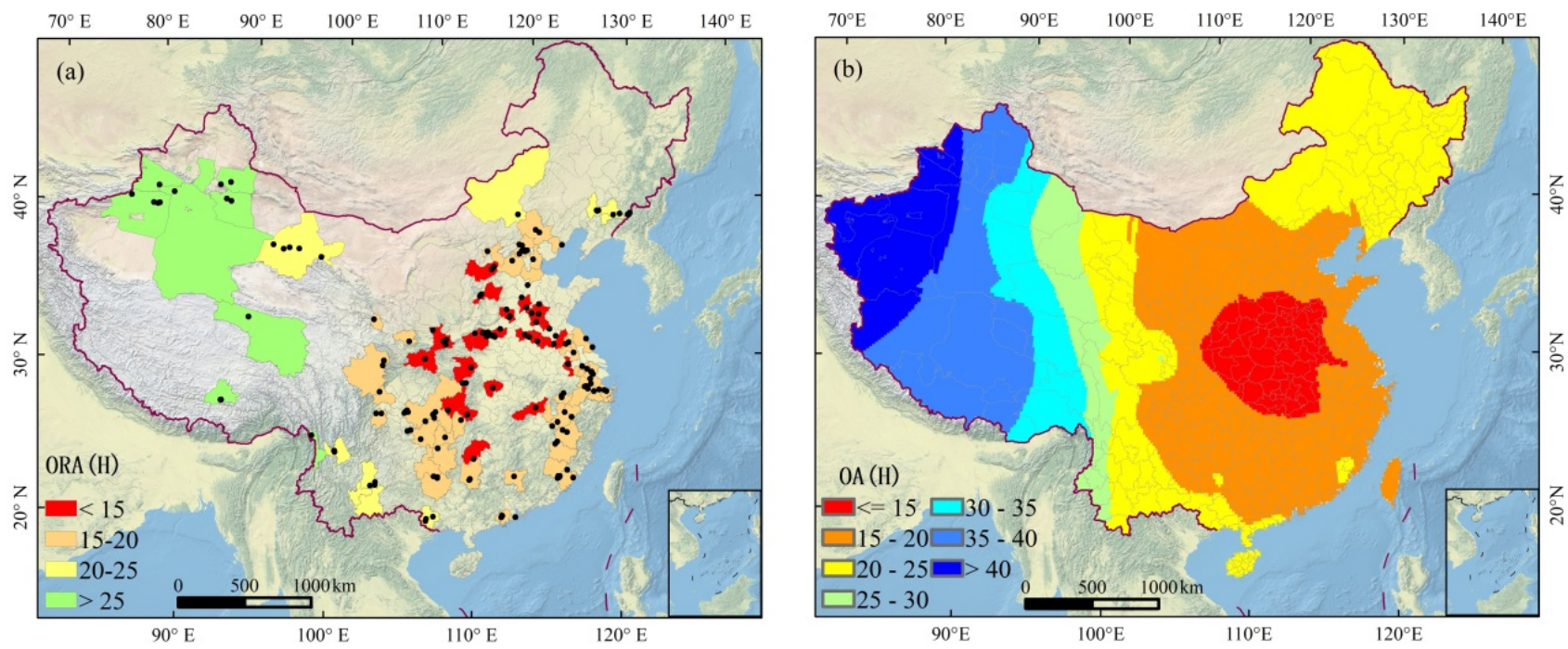

Figure 4. Spataial time-cost of Outer-Regional Accessibility (ORA) and Overall Accessibility (OA) of China's Heritage Sites in hours $(\mathrm{H})$. In plots, (a) denotes the time cost of outer-regional accessibility in space; (b) denotes the total time-cost of inter- and outer- regional accessibility in space.

To assess the overall accessibility of a World Heritage Site, inter-regional and outerregional accessibilities were comprehensively considered. In this paper, the total time spent to travel from the inter-region and outer-region was defined as the overall accessibility. The overall accessibility of a World Heritage Site was interpolated over all of China using a method of spatial Kriging interpolation (Figure $4 b$ ). The overall accessibility in the middle region was very good with a time cost within $20 \mathrm{~h}$, especially in the central plain region between the Yellow River and the Yangtze with a time cost of $<15 \mathrm{~h}$. The time of overall accessibility to a World Heritage Site increased when moving from the central region of $\mathrm{China}$ to the western and northeastern regions, ranging from $<15 \mathrm{~h}$ to $>40 \mathrm{~h}$. Most regions presented a high accessibility with a low time cost within $20 \mathrm{~h}$, while several regions were more than $30 \mathrm{~h}$, such as Xinjiang and the Qinghai-Tibet Plateau. Regions covered by large mountains were characterized by bad natural environments, poor road networks, under population, etc. The overall accessibility of Chinese World Heritage Sites was high, with an average time cost of $25.51 \mathrm{~h}$.

\section{Discussion}

\subsection{Evolution of World Heritage in China}

There were discrepancies in the study of the development process of China's World Heritage Projects in different periods. The development process was divided into three stages based on the protection and management of World Heritage Sites in China during the period 1985-2012 [10,23,24]; beginning in 1985-1997, evolving in 1998-2003 and deepening after 2004. Li and Wang [25] divided this period into four stages according to a percentage of the number of sites out of the total; beginning in 1985-1997, evolution in 1998-2003, deepening in 2004-2012 and steady development after 2012. Some researchers have also divided them into three stages depending on the number of Chinese World Heritage Projects from 1987 to 2014 [26,27]; beginning in 1987-1990, rapid development in 1991-2000 and stable development after 2001. Mu and Yu also divided them into three stages [21,28]; exploration in 1987-1989, transition in 1990-2002, and maturation in 2003-2018. These differences were mainly caused by changes in the number and academic cognition of World Heritage Projects in different periods. Although China's World Heritage Projects were 
not listed in the World Heritage List before 1985, a large number of studies on World Heritage were conducted, such as the work of nomination and field observations of World Heritage in China. However, this exploratory work was not included in these studies of the developmental phases. Most exploratory work before 1985, however, were not neglected. Therefore, we divided them into four stages in this paper, i.e., exploratory before 1985, evolution in 1986-1999, accelerated development in 2000-2003, and stable development since 2004. Moreover, the Cairns Decision limited the number of new nominations to be examined each year by the Committee. Furthermore, the number of nominations to be submitted by each State Party was limited to one, except for those State Parties that had no properties on the World Heritage List who would have the opportunity to propose two or three nominations (https:/ / whc.unesco.org/en/activities/590/ (accessed on 23 December 2021)) [28]. The development of World Heritage has progressed into a period with stable and planned growth.

\subsection{Spatial feature of World Heritage in China}

With the development of World Heritage Projects and an increasing eagerness to explore World Heritage Sites in China, research on the spatial characteristics of China's World Heritage Projects has increased [16,27]. The results in the literature were largely consistent with our results (Figure 2). Most World Heritage Sites are distributed in the middle of China, with this area accounting for significantly more sites than western or northeastern China. We also found that the spatial correlation of the heritage sites was not significant. In addition, the analysis of cold-hot spots showed that the hot spots were mainly distributed in the central region, northwestern region, and east coast of China. In these regions, the regional spatial correlation effect was significant and the high values clustered together at Beijing-Tianjin-Hebei, Xi'an, Luoyang-Zhengzhou, Chongqing, the Yangtze River Delta, the Pearl River Delta, and the Hexi Corridor. The other Chinese regions with heritage sites are distributed in scattered points, and there are few heritage projects in the northeastern region or the Qinghai-Tibet Plateau. Based on Chinese road network data in 2016, the traffic road network density of China was calculated [21]. The time cost was used to reveal the accessibility of Chinese World Heritage Sites in this work, including the inter-regional, outer-regional, and overall accessibility. This method helped us to understand the road accessibility in terms of World Heritage Sites, and the results will be useful to tourists planning to travel to these sites.

\subsection{Traffic Accessibility}

It is widely accepted that traffic road accessibility is an important factor affecting tourism [29-32]. Many tourists do not like to travel long distances, so the geography of the location plays an important role in the factor considered by travel. Tourists like to choose destinations that are easily accessible and do not require days of travelling. As such, the assessment of internal regional accessibility is very important. Overall accessibility can provide a key reference for those giving tourists with an enriching experience. Therefore, the good traffic accessibility of China's World Heritage Sites will help meet the challenges facing tourism. It should also be noted that good accessibility does not fully inform the decision of a tourist destination. The development of tourist destinations depends on several factors, including its population, traffic accessibility, attractiveness, and topographical characteristics. However, traffic accessibility is the primary condition for travel. Good traffic accessibility suits the elderly, children, and staff with short holidays, all of whom may desire to avoid physical discomfort during a journey.

\section{Conclusions}

Based on the dataset of China's World Heritage Projects, we evaluated the spatiotemporal characteristics and accessibility of the included heritage sites using a statistical method and spatial analysis tools. By 2020, there were 55 World Heritage Projects in China, including 37 Cultural Heritage Sites, 14 Natural Heritage Sites, and 4 Mixed (Double) 
Heritage Sites. The development of World Heritage in China can be divided into four stages: exploratory before 1985, evolution in 1986-1999, accelerated development in 2000-2003, and stable development since 2004. The global spatial correlation was not significant in terms of the spatial distribution of the World Heritage Sites, while the regional spatial correlation was very significant. Cold-hot spots analysis showed that the hot spots were mainly distributed in the central and northwestern regions.

The average accessibility was $1.03 \mathrm{~h}$, which showed a low time cost and generally strong accessibility. In addition, the assessment of the overall accessibility indicated that the average time cost of China's World Heritage Sites was $25.51 \mathrm{~h}$. The overall accessibility of the central plain regions of China was very high, with a mean time cost of within $15 \mathrm{~h}$, which shows great potential for travel to World Heritage Sites in China. It was also noted that the good traffic accessibility of a World Heritage Site as a tourism destination does not completely determine a well-developed level of tourism, which may be suitable for more people, such as the elderly, children, and travelers with shorter holidays. The traffic accessibility results also had some limitations due to calculated under-assumptions of ideal conditions such as traffic congestion, weather changes at destinations, and recommendations from friends and relatives. Therefore, the development of tourist destinations for China's World Heritage Sites should comprehensively consider tourist income, population, geographical variables, and topographical characteristics.

Author Contributions: Y.C. (Yanjun Che), Y.C. (Yun Cao) and R.W. contributed to the study design and writing the manuscript; J.L. and L.C. performed the data processing and statistical analysis; J.W. check the formal analysis. All authors have read and agreed to the published version of the manuscript.

Funding: This research was supported by the National Natural Science Foundation of China (No.42101135), the Jiangxi Provincial Natural Science Foundation (No.20202BAB213013), the project of Environmental Monitoring and Protection in the World Natural Heritage Site in the Longhu Mountains from the Nanchang Base of International Centre on Space Technologies for Natural and Cultural Heritage under the Auspices of UNESCO (HIST-NB) and the Open Fund of the Key Laboratory of Poyang Lake Wetland and Watershed Research (Jiangxi Normal University), Ministry of Education (PK2020002).

Institutional Review Board Statement: Not applicable.

Informed Consent Statement: Not applicable.

Data Availability Statement: The data presented in this study are available on request from the corresponding author.

Conflicts of Interest: The authors declare no conflict of interest.

\section{References}

1. Khalaf, R.W. World Heritage on the Move: Abandoning the Assessment of Authenticity to Meet the Challenges of the Twenty-First Century. Heritage 2021, 4, 371-386. [CrossRef]

2. Li, J.; Zhang, X.; Zheng, S. A preliminary discussion on the way out for World Heritages. Tour. Trib. 2006, 21, 5.

3. Tao, W. Research on the sustainable tourist development of "World Heritage" in China. Tour. Trib. 2000, 5, 35-41.

4. Lior, B.; Nir, A.; Jackie, F. UNESCO World Heritage Sites: Shared shrines or contested sanctuaries? The case of the Buddhist temples of Luang Prabang, Laos. J. Herit. Tour. 2021, 16, 1-19.

5. UNESCO. The Operational Guidelines for the Implementation of the World Heritage Convention; UNESCO: Paris, France, 2008.

6. Li, W.; Min, Q.; Sun, Y. Discussion on the scientific research of natural and cultural heritage. Geogr. Res. 2006, 25, 561-569.

7. Leng, Z.; Zhang, T. Research progress in China's World Heritage Site tourism and it's prospect. Hum. Geogr. $2009,24,111-115$.

8. Ding, C. Comparative Research on the Proportion and Combination Sorts of Adopted Criterions of World Heritage between the Globe and China. Acta Sci. Nat. Univ. Pekin. 2006, 42, 231-237.

9. UNESCO. World Heritage List; UNESCO: Paris, France, 2021.

10. Chen, Y.; Zhao, X. Protection and Utilization of China's World Heritages. Acta Sci. Nat. Univ. Pekin. 2003, 39, $572-578$.

11. Lin, Y.; Chen, M.H.; Lin, B.; Tseng, S.; Su, C. Nonlinear impact of World Heritage Sites on China's tourism expansion. Tour. Econ. 2021, 27, 795-819. [CrossRef] 
12. Burbano, D.V.; Meredith, T.C. Effects of tourism growth in a UNESCO World Heritage Site: Resource-based livelihood diversification in the Galapagos Islands, Ecuador. J. Sustain. Tour. 2021, 29, 1270-1289. [CrossRef]

13. $\mathrm{Wu}, \mathrm{B} . ; \mathrm{Li}, \mathrm{M} . ;$ Huang, G. A study on relationship of conservation and tourism demand of world heritage sites in China. Geogr. Res. 2002, 21, 617-626.

14. Li, P.; Lu, Y. Review and prospectation of accessibility research. Prog. Geogr. 2005, 24, 69-78.

15. Li, J.; Krishnamurthy, S.; Pereira, R.A.; van Wesemael, P. Imagine the Old Town of Lijiang: Contextualising community participation for urban heritage management in China. Habitat Int. 2021, 108, 102321. [CrossRef]

16. Jia, Z.; Wu, M.; Yang, D.; Ma, Y. Research on quantitative and spatial distribution of Word Heritages in China. J. Southwest For. Univ. (Soc. Sci.) 2017, 1, 100-104.

17. Zhou, Y.; Deng, Z.; Shi, J.; Ma, D.; Zheng, X. Tourist Market Potential of the World Heritage Tourism Destination in China. Econ. Geogr. 2019, 39, 216-222.

18. Ord, J.K.; Getis, A. Local Spatial Autocorrelation Statistics: Distributional Issues and an Application. Geogr. Anal. 1995, 27, 286-306. [CrossRef]

19. Getis, A.; Ord, J.K. The Analysis of Spatial Association by Use of Distance Statistics. Geogr. Anal. 1992, 24, 189-206. [CrossRef]

20. Wang, Z.; Zhang, M. Spatio-Temporal Evolution Characteristics of Beijing Subway Network and Its Evolution Mechanism. Econ. Geogr. 2021, 41, 1-9.

21. Mu, Z.; You, W.; Zhang, X.; Lin, M.; He, D. Spatial patterns and transportation accessibility analysis of World Heritage in China. Mt. Res. 2020, 38, 436-448.

22. Dou, W.; Wang, S.; Han, T.; Xie, J. Measurement of accessibility and market potential of ski resorts in China. Sci. Geogr. Sin. 2021, 41, 319-327.

23. Yang, R.; Zhao, Z.; Zhuang, Y. Study on the concept of World Mixed Heritage. Chin. Landsc. Archit. 2009, 25, 1-8.

24. Yang, R.; Zhao, Z.; Zhuang, Y. Retrospect and Prospect: Protection and Management of World Natural and Mixed Heritage in China. Chin. Landsc. Archit. 2012, 28, 55-62.

25. Li, J.; Wang, M. Review of the development of World Natural Heritage in China. Study Nat. Cult. Herit. $2020,5,3-7$.

26. Wang, X.; Wei, J.; Hu, C. The spatial distribution of World Heritages in China. Geogr. Res. 2010, 29, $2080-2088$.

27. Liu, J.; Le, H. Distribution and recognition of Chinese World Heritage in the time-spatial perspective. J. Yancheng Inst. Technol. (Soc. Sci. Ed.) 2016, 29, 44-48.

28. Yu, Z.; Tian, X.; Chen, Y. Analysis of Characteristics and Cause of Spatial Distribution of theWorld Heritage in China. J. Nat. Resour. 2015, 30, 1762-1773.

29. Wang, S.; Xie, J.; Zhou, L. China's glacier tourism: Potential evaluation and spatial planning. J. Destin. Mark. Manag. 2020, 18, 100506. [CrossRef]

30. Pere, S.S.; Augusto, V.D. Drivers of airport scheduled traffic in European winter tourism areas: Infrastructure, accessibility, competition and catchment area. J. Air Transp. Manag. 2019, 81, 101723. [CrossRef]

31. Li, G.; Li, B.; Ju, M.; Zhang, Z. Discussion on Integrated Traffic Planning(ITP) of New Tourism Town upon Sustainable Development and Livable Request. Transp. Res. Procedia 2017, 25, 3398-3411. [CrossRef]

32. Santos, F.; Almeida, A.; Martins, C.; Gonçalves, R.; Martins, J. Using POI functionality and accessibility levels for delivering personalized tourism recommendations. Comput. Environ. Urban Syst. 2019, 77, 101173. [CrossRef] 